Љиљана Рогач Мијатовић

Факултет драмских уметности

Универзитет уметности у Београду
UDC: 007:009

UDC: 009:001

DOI: 10.18485/dh.2015.1.ch1

\title{
ХУМАНИСТИКА, ИНТЕРДИСЦИПЛИНАРНОСТ И ПРОИЗВОДЊА ЗНАҢА У ДИГИТАЛНОМ ДОБУ
}

\section{Сажетак}

На почетку двадесет првог века, пред хуманистичке науке поставља се захтев да изграде хуманизам на новим основама, чиме се најављује нови епистемолошки и етички заокрет, са значењем другачије концепције знања, како научне културе тако и хуманистичке културе. Постоји очигледна потреба за интердисциплинарним, трансформативним хуманистичким наукама оријентисаним ка будућности. Интердисциплинарни рад отвара посебне методолошке и епистемолошке изазове са научним и педагошким импликацијама. На који начин се одвија дијалог и размена између дисциплина у дигиталном добу? Како успоставити разумевање каузалности и дискурса технологије, културе и производње знања? У раду се заступа теза о неопходности развијања критичког мултиперспективног приступа савременој производњи знања у хуманистичким наукама и референцијалности кроз нове методе и средстава за документацију, нарочито у дигиталној хуманистици, а у циљу развоја одрживих екологија знања.

Кључнеречи:дигиталнахуманистика, интердисциплинарност, епистемологија, big data, дигитални обрт

\section{Криза хуманистике}

Развој нових технологија у све већој мери утиче на промене друштвене динамике и културних пракси, што доводи до све веће конвергенције појединаца и њихових окружења. Технолошки прогрес, глобализација и мултиполаризовани свет у дигиталном добу довели су до низа тензија и последица које се одражавају и на интелектуални рад у хуманистици. Хуманистичке науке суочавају се са изазовима и напорима да се ухвате у коштац са комплексношћу 
садашњости, да створе ново знање које превазилази искуључиво текстуалне изворе, применом нових методологија и теорија. Криза хуманистике огледа се превасходно у тзв. кризи темеља у прозиводњи и исходиштима знања. Реч је, наиме, о кризи смисла у ери технолошке доминације. Дилеме у вези са правцем развоја хуманистике односе се делом и на тренд „ослобађања“ науке у правцу редефинисања односа и превазилажења граница између природних и хуманистичких наука, те новим „археологијама знања“ (Фуко, 1998). У новијим формама интелектуалног дискурса „природна наука постаје јавна култура“. То указује на савремену тенденцију натурализма у епистемолошком и етичком контексту научног сазнања (Камерер, 2013: 1417). Ове тенденције јављају се уместо путање стабилизације у склопу те „геометрије“, а она би требало да окарактерише трагање за „новом традицијом“ мишљења и деловања.

Пред хуманистичке науке поставља се захтев да постану више релевантне како у погледу њиховог епистемолошког статуса, тако и у погледу тематског и проблемског оквира. Тиме се најављује нови епистемолошки и етички заокрет, са значењем другачије концепције знања, како научне културе тако и хуманистичке културе. У том смислу, трагање за новим, интердисциплинарним и трансдисциплинарним приступима хуманистичким наукама оријентисаним ка будућности отвара низ сложених питања са методолошким, практичним и политичким импликацијама.

Како се одвија производња и дисеминација знања у дигиталном добу? У којој мери и на који начин је могуће градити мостове међу дисциплинама? Како обновити хуманистику у сенци дигиталног? Који су начини изградње критичких приступа дигиталним средствима и дигиталној култури у хуманистици?

Оквир овог новог поља је много шири од компјутерске обраде података - он се једнако односи на технолошки приступ хуманистици, и на хуманистички приступ технологијама и обликовања знања у тим контекстима. Дигитално доба довело је до промене методологија и техника истраживања, али још више до промене исходишта сазнања. До сада, већина стратегија имала је за циљ дигиталну подршку хуманистичким истраживањима применом дигиталних медија, тако да је 
фокус углавном био на пружању подршке већ успостављеним темама хуманистичких истраживања. Проширени смисао дигитализације јесте у томе што се тиме заправо преиспитују, мењају или поново откривају неке од основних претпоставки хуманистичких наука. На тај начин се потцртава још један стари/нови изазов за хуманистику, а то је постојање трајне тензије између теорије и институционализоване праксе.

\section{(Интер)дисциплинарност и (гео)политике производње знања}

Постоји само једна перспектива виђења, само једна перспектива „знања“; и што више дозволимо да говоримо о нечему, што више очију, разних очију смо у стању да користимо за исту ствар, потпунији ће бити наш „концепт“ ствари, наша „објективност“.

(Ниче, Генеалогија морала)

Погледом „више очију, разних очију“ из различитих дисциплина и теорија у предмету истраживања, како је Ниче (Friedrich Nietzsche) говорио, могуће је изгубити нешто од утемељене кохерентности истраживачког поступка, али је такође могуће много и добити у погледу потпунијег разумевања стварног „стања ствари“ (Рогач Мијатовић, 2014: 22). Тиме се предлаже управо један другачији приступ изградњи знања, који заузима више стратегија разумевања и, опирући се једностраним концепцијама, проширује „хоризонт значења“. Мултиперспективност, дакле, иде „руку под руку“ са интердисциплинарношћу, уколико је постављени циљ изградња знања које ће моћи да одговори на изазове савременог света.

Производња знања постала је веома разноврсно, али и много оспоравано поље интелектуалног деловања. Преобликовање дицсиплна и институција производње знања, као и реконструкција саме истраживачке праксе кроз призму „геополитике знања“ (Минголо) односе се све више на политичка питања у глобалном контексту. Стога је важно поставити питање: Како преовлађујући трендови у производњи знања обликују наше истраживачке програме? Поред тога, постоји и претпоставка о критичкој, етичкој и политичкој 
одговорности самиих истраживача у производњи, дисеминацији, трансформацији и усвајању знања, као и стварању мрежа знања.

Почело је да бива јасно да епистемолошка борба око тога шта је легитимно знање више није била борба око питања ко ће имати власт над знањем о природи (до 18. века природњаци су већ били убедљиво освојили ексклузивна права у овој области) него око тога ко ће имати власт над знањем о човеку. (Валерштајн, 1997: 15)

Улога хуманистичких наука данас усмерена је на знање „како“ (методологије) и стога се не може поистоветити са знањем „шта“ и разумевањем „зашто“, који суподједнако важни. Дакле, проширивање поља деловања кроз интердисциплинарни рад јавља се као могући пут за проширивање перспектива у производњи знања. Интердисциплинарни рад ствара посебне методолошке и епистемолошке изазове са научним и педагошким импликацијама. За хуманистичке науке, интер- и посебно транс-дисциплинарни рад представљају амбициозне циљеве и отварају многа питања. Под којим условима се може одвијати истински дијалог и размена између дисциплина? Који инструменти иду у прилог таквим истраживањима? Какви алтернативни оквири могу бити доведени у први план у развијању иновативних приступа истраживањима у дигитално доба? Који су оквири или параметри који окружују наше истраживачке праксе у хуманистичким наукама?

Реконструкција истраживачких пракси подразумева комбинацију метода, нове методологије и нова исходишта истраживања, као и нове облике дисеминације резултата, као што су мреже знања, е-издаваштво, е-учење, итд. Посебан фокус је на умреженим оквирима производње знања, за истраживање феномена који су у настајању, а у оквиру нових истраживачких поља, као што је дигитална хуманистика. Мреже знања (knowledge networks) јављају се као значајан фактор за производњу знања нарочито изван симболичких оквира позитивизма и емпиризма.

Финални производ науке сада није ни коначан, нити је уопште производ. То је сама мрежа - беспрекорно повезивање научника, података, методологија, хипотеза, теорија, чињеница, спекулација, инструмената, читања, амбиција, контроверзи, школа мисли, уџбеника, факултета, колаборација и несугласица... (Weinberger, 2011: 156) 
Овом констатацијом се указује на нови „обрт“ у хуманистичким наукама, који своје корене налази управо у убрзаном развоју дигиталних и нових технологија. А технологија заправо никада није неутрална.

\section{Дигитални „обрт“ у хуманистици и парадигма Big Data}

У текућој новој технолошкој револуцији, дифузија логике умрежавања, као и само процесуирање података употребом дигиталних технологија значајно мењају процесе производње, односе моћи, схватање културе, па и свакодневно животно искуство. Мреже су нова друштвена морфологија друштва (Castells, 2000: 469). Дигиталне технологије из основа су уздрмале традиционално поимање и природу истраживачког процеса. Започео је дугорочни и по свим изгледима трајни процес трансформације значења онога што се подразумева под истраживањем, као и његовог епистемолошог и онтолошког статуса. Нови медији увели су нумеричку репрезентацију не само објеката већ и саме стварности (Manovich, 2001). Тиме и питање истине (као исходишта сазнања) у ери (нових) медија бива интерпретирано посредством „бесконачног, технолошки изведеног мултиплицирања ... као мношто истина“ (Вуксановић, 2011: 13). Информатички односно дигитални „обрт“ захватио је и хуманистичке науке, постављајући нове изазове већ пољуљаним темељима овог поља, и напорима да се ухвате у коштац са сложеношћу садашњости. Овај информатички тренд огледа се у текућој дигитализацији уметности и пројеката хуманистичких и друштвених наука, „у правцу већег спајања података, бројки и слова, спајања које у великој мери олакшава њихов хомогени третман као бинарних јединица у рачунарима и помоћу њих" (Latour, 1986: 16). Наступило је доба „великих података“.

Дигитална хуманистика прешла је пут од „рачунарства у хуманистици“, техничке подршке у великим пројектима дигитализације и успостављања технолошке инфраструктуре за истраживања хуманистичких наука, до аутентичног интелектуалног стремљења ка новим дисциплинарним парадигмама, конвергентним пољима истраживања и хибридним методологијама, развијајући другачије 
начине репрезентације и посредовања стварности. Како истичу Шнап и Презнер „Први талас дигиталних хуманистичких наука крајем деведесетих година прошлог века и почетком 21. века био је превасходно усредсређен на велике пројекте дигитализације и успостављање технолошке инфраструктуре, док је садашњи други талас дигиталне хуманистике, који се може назвати 'дигитална хуманистика 2.0', дубоко генеративан" (Schnapp and Presner, 2009). Од квантитативне ка квалитативној фази развоја дигиталне хуманистике, дошло се до конвергенције не само међу „хуманистичким дисциплинама, већ и између уметности, науке и технологије“ (Вранеш, 2015).

Импликације нове технолошке парадигме на друштвено памћење су још увек „страна земља“ и привлаче све већу пажњу студија сећања нарочито кроз појам дигиталног памћења (digital memory). Могућности за похрањивање и процесуирање велике количине података, довеле су и до нових изазова у погледу капацитета за очување културног памћења. У проучавању дигиталног памћења, није довољно само припојити постојеће термине са префиксом „дигитално". Да би се адекватно примењивали концепти дигиталних артефакта, меморијалних веб страница, дигиталних архива, интернет музеја и дигитализованог наслеђа уопште неопходно је дубље разумевање језика нових медија (Manovich, 2001). Међутим, дигиталне архиве, колекције и базе података нису само подршка истраживању; оне и по структури и по садржају припадају информатичкој, дигиталној логици, која је уткана у дигиталне репрезентације физичких објеката, текстова, као и у артефакте који су настали као дигитални. Друштвено памћење са применом дигиталних алатки и претраживача губи фиксиране категоризације и селективне „утабане” стазе сазнања информација. Такође, не постоје интитуционалне праксе у дигиталном окружењу које би приписале веб сајтовима, блоговима, апликацијама и сл. статус канона који улази у културно сећање. Дигитализација нуди нове могућности комуницирања сећања, али наилази и на изазове у проналажењу смислених начина такве комуникације у променљивом друштвеном, културном и технолошком окружењу. Стога дигиталне методе и инструменти за документацију, истраживање и интерпретацију имају дубље ефекте 
на стварање / „склапање“ знања. Тако се фокус пребацује на трагање за новим матрицама података и кодова.

У духу реторике о растућем утицају инструмената глобалног умреженог друштва, феномен „Big Data“ (великих података) ушао је на велика врата и велике науке и великог бизниса, будећи и наду и страх пред променама које доноси у добу неизвесности. Да ли је „Big Data“ само још једна buzz word у глобалној култури технолошког прогреса или део преокрета у дефинисању, и стварању знања? Како дигитални "обрт“ утиче на епистемолошке промене, односно како доводи до промене природе сазнања? И како проблематизовати основне претпоставке и онтолошку базу истраживања и стварања знања?

O моћи „Big Data“ и аутономији дигиталне концепције, Крис Андерсон (Chris Anderson) уредник часописа Wired, износи уверење, да „Уз довољно података, бројке говоре саме за себе [...] Нова доступност огромне количине података, заједно са статистичким алатима за обраду ових бројки, нуди потпуно нови начин разумевања света“ (Anderson, 2008). „Big Data“, дакле, учествују у преобликовању кључних питања о успостављању знања, процеса истраживања, начина како би требало баратати информацијама, као и у вези са природом и категоризацијом стварности. Овај сложени феномен указује на радикалну промену у начину на који размишљамо о истраживању на нивоу епистемологије и етике, доводећи у питање методологије сазнања, као и саме дефиниције друштвеног живота (Boyd; Crawford, 2012).

Обећања „Big Data“ парадигме хуманистичким наукама управо иду у сусрет изазовима са којима се суочавају хуманистичке науке, које се тичу одржања легитимног места унутар академских дисциплина, јачања објективности и квантитативних резултата, преиспитивања постојећих истраживачких пракси, отварања за нове концепције знања. Теоретичар дигиталне хуманистике Дејвид Бери (David Berry) отвара питање о могућностима радикалнијег ослањања на технологију и техничка средства: „Могу ли нас софтвер и (дигитални) код повести изван индивидуализујућих трендова блогова, коментара, Твиттер "фидова“, и тако даље, и омогућити нешто заиста колаборативно нешто као супер-критичко размишљање које генерише идеје, начине размишљања, теорије и нове праксе?“ (Berry, 2011: 8). 
Критичко преиспитивање основних претпоставки „Big Data“ парадигме указује на ограничења у погледу стварања знања, од питања објективности и одговорности, релевантности, до самог значења, етичких и политичких импликација. „Велики подаци“ као и остали елементи дигиталног истраживачког материјала обликовани су самом технологијом и дигиталном платформом у употреби и не могу представљати идеални узорак, неутрални поглед на свет, чисту чињеницу. „Big Data“ не објашњавају сами себе, тако да је неизоставно потребан неки „субјективни филтер“ то јест интерпретација. То указује на илузију о саморегулишућем механизму који би имао способност откривања увида и матрица података у условима вакуума, без икакве потребе за контекстуализацијом, дискурзивним обликовањем и теоријском аргументацијом. Дакле, истраживање у дигиталном окружењу није неутрална пракса која производи поглед ниоткуда, већ је смештено у одређеним контекстима, а подаци одражавају технике и методе које су употребљене како би се до њих дошло, што има значајне импликације на резултате и интерпретације истраживања.

У ери „великих података“ на делу је „софтверизација“ интелектуалног рада, који се у одређеној мери лишава рефлексивности и критичког промишљања вредносних поставки и односа моћи. Будући да софтвер обезбеђује и медиј и контекст, истраживачки рад се „ослобађа“ раније успостављених методолошких вештина хуманистике, као што су полифонија „гласова“ - различитост перспектива, историјски контекст, аналитичка дубина, критика и интерпретација. Дигиталне стуктуре обезбеђују скоро дестабилизујуће количине информација и базе података знања, претендујући на заузимање самог поља људског знања. У дигиталном „склапању“ (па и „расклапању“) стварности помоћу нових, информатички детерминисаних дигиталних метода за разумевање стварности производи се ново знање.

Интерпретацијом старогрчког концепта phronesis могуће је указати на контрастну улогу интелектуалног рада спрам овог новог знања, вештине (techne, craft) - вештине великих бројева. Док је techne везана за технологију, технолошко знање и know-how, phronesis инсистира на вредностима, практичном знању и етици. Дакле, потребно је про- 
блематизовати „рачунарски“, технички аспект дигиталне хуманистике како би се омогућило критичко промишљање о трансформацији хуманистичког знања у 21. веку.

\section{Ка одрживим екологијама знања у хуманистици}

Намера овог рада била је да укаже на неопходност критичког истраживања нових облика емпиризма који најављују „крај теорије“ и почетак нове науке вођене (великим) подацима, нарочито у контексту дигиталних хуманистичких наука. Поменути увиди и резултати пројекта указују на утемељеност теоријских претпоставки и ставова у вези са произовдњом знања кроз интердисциплинарни рад и улоге које хуманистика у том контексту има. Нови токови научно-истраживачког рада и производње знања једним делом воде од аутономије хуманистике до интеграције са другим дисциплинама. Мреже знања и дисеминација резултата у дигиталном окружењу свакако су значајан оквир за даљи развој поља дигиталне хуманистике у ширем смислу. Пост-конвенционални хуманистички критички и креативни истраживачки рад обухвата следеће принципе: плуралност као битна одлика, идеја промене перспективе, трансдицсиплинарна концепција, практично оријентисана истраживања, препознавање етичких питања, итд.

Ми као истраживачи имамо критичку, етичку и политичку одговорност у производњи, ширењу, трансформацији знања у оквиру хуманистичких наука. Стога се изазов да се хуманистичке науке учине релевантнијима тиче превасходно одговорности и објективности (и то не само у погледу квантификације резултата истраживања). То има одређене етичке и политичке импликације - спремност истраживача да пруже одговоре на све сложеније проблеме са потенцијално глобалним последицама, као и да се баве питањима која су релевантна за друштава данашњице и сутрашњице. Хуманистичке науке би требало да буду њихова критичка свест и основа у потрази за смислом, идентитетом и алтернативним визијама хуманитета у добу технолошке доминације. 


\section{Литература}

Anderson, Chris. The End of Theory: The Data Deluge Makes the Scientific Method Obsolete. Wired Magazine. 2008. Web. 8 Dec. 2015.

Berry, David M. The Computational Turn: Thinking About the Digital Humanities, Culture Machine, Vol 12. 2011. Web. Dec. 2015.

Boyd, Danah and Crawford, Kate. Critical questions for big data. Information, Communication and Society 15(5), 2012. pp. 662-679.

Burke, Kenneth. Language as Symbolic Action: Essays on Life, Literature, and Method. Berkeley: University of California Press. 1968. Print.

Валерштајн, Имануел и др. Како отворити друштвене науке, Подгорица: ЦИД. 1997.

Вранеш, Александра. „Дигитална хуманистика и сајбер феминизам“, Књиженство: часопис за студије књижевности, рода и културе, год. 5, бр. 5, 2015. Web. 8 Dec. 2015.

Вуксановић, Дивна. Филозофија медија 2: Онтологија, естетика, критика. Београд: Факултет драмских уметности, Чигоја штампа. 2011.

Камерер, Ева. „Трећа култура: филозофија и наука“, Култура: часопис за теорију и социологију културе и културну политику, Бр. 141, 2013. стр. 11-22.

Latour, Bruno. 'Visualization and Cognition: Thinking with Eyes and Hands', Knowledge and Society, vol. 6, 1986. pp. 1-40.

Manovich, Lev. The Language of New Media, MIT. 2001. Print.

Mignolo, Walte. "Globalization and the Geopolitics of Knowledge: The Role of the Humanities in the Corporate University." Nepantla: Views from South 4.1. 2003. pp. 97-119. Web 8 Sep. 2015.

Ниче, Фридрих. С оне стране добра и зла; Генеалогија морала. Београд: Дерета. 2011.

Рогач Мијатовић, Љиљана. Културна дипломатија и идентитет србије. „Мапирање поља“. Београд: Факултет драмских уметности, CLIO. 2014.

Schnapp, J. \& Presner, P. ‘Digital Humanities Manifesto 2.0', 2009. Web 14 October 2010

Presner, T. 'Digital Humanities 2.0: A Report on Knowledge', 2010. Web 15 October 2010 Фуко, Мишел. Археологија знања, Београд: Плато. 1998.

Castells, Manuel. The Rise of The Network Society: The Information Age: Economy, Society and Culture. John Wiley \& Sons. 2000. Print.

Weinberger, David. Too big to know: Rethinking knowledge now that the facts aren't the facts, experts are everywhere, and the smartest person in the room is the room. New York: Basic Books. 2011. Print. 


\title{
Ljiljana Rogač Mijatović
}

Faculty of Dramatic Arts in Belgrade

\section{THE HUMANITIES, INTERDISCIPLINARITY AND PRODUCTION OF KNOWLEDGE IN THE DIGITAL AGE CASE ST UDY COST ACTION "INVESTIGATING CULTURAL SUSTAINABILITY"}

\begin{abstract}
Summary
At the beginning of 21st century, the request that is being put upon the humanities is to build humanism on new grounds, thus announcing a new epistemological and ethical turn, with a meaning of the new composition of both scientific culture and humanistic culture. There is an obvious need for interdisciplinary, transformative and future oriented humanities. Interdisciplinary work generates specific methodological and epistemological challenges with both scientific and pedagogical implications. How can a genuine dialogue and exchanges between disciplines take place in the digital age? The scope of this paper will by means of qualitative, textual, and critical discourse analysis address issues that represent some of the core challenges for the humanities in the digital age. In the case of the COST project "Ivestigating Cultural sustainability Research" the paper will analyze the assumptions, trends and outcomes of the interdisciplinary work, as well as of knowledge production and dissemination of scientific results in the digital environment.
\end{abstract}

Key words: humanities, interdisciplinarity, COST, methodology, epistemology 